\title{
Effect of Alteration Zones on Water Quality: A Case Study from Biga Peninsula, Turkey
}

\author{
Alper Baba • Orhan Gunduz
}

Received: 19 July 2009/ Accepted: 28 September 2009/Published online: 20 October 2009

(C) Springer Science+Business Media, LLC 2009

\begin{abstract}
Widespread and intense zones of silicified, propylitic, and argillic alteration can be found in the Çan volcanics of Biga Peninsula, northwest Turkey. Most of the springs in the study area surface out from the boundary between fractured aquifer (silicified zone) and impervious boundary (argillic zone). This study focuses on two such springs in Kirazlı area (Kirazlı and Balaban springs) with a distinct quality pattern. Accordingly, field parameters (temperature, $\mathrm{pH}$, and electrical conductivity), major anion and cation (sodium, potassium, calcium, magnesium, chloride, bicarbonate, and sulfate), heavy metals (aluminum, arsenic, barium, chromium, cobalt, cupper, iron, lithium, manganese, nickel, lead, and zinc), and isotopes (oxygen-18, deuterium, and tritium) were determined in water samples taken from these springs during 2005 through 2007. The chemical analyses showed that aluminum concentrations were found to be two orders of magnitude greater in Kirazlı waters (mean value 13813.25 $\mu \mathrm{g} / \mathrm{L}$ ). The levels of this element exceeded the maximum allowable limits given in national and international standards for drinking-water quality. In addition, Balaban and Kirazlı springs are $>55$ years old according to their tritium levels; Kirazlı spring is older than Balaban spring. Kirazlı spring is also more enriched than Balaban spring based in oxygen18 and deuterium values. Furthermore, Kirazlı spring water has been in contact with altered rocks longer than Balaban
\end{abstract}

\footnotetext{
A. Baba $(\bowtie)$ Izmir, Turkey

e-mail: alperbaba@iyte.edu.tr

O. Gunduz

Department of Environmental Engineering,

Dokuz Eylul University, Izmir, Turkey

e-mail: orhan.gunduz@deu.edu.tr
}

Department of Civil Engineering, Izmir Institute of Technology, spring water, according to its relatively high chloride and electrical conductivity values.

Water-rock interaction is an important topic influencing the water quality as well as human health. Particularly in altered systems, these interactions are more important for local inhabitants using water for drinking purposes because the water in such systems might contain increased levels of certain elements that are potentially detrimental to human health. Thus, these interactions should be assessed carefully in areas of complex geology where rocks formed as a result of hydrothermal system are predominant.

Hydrothermal fluids carry metals in solution, coming either from a nearby igneous source, from leaching of subsurface rocks, or both (Henley et al. 1984). These fluids then alter other rocks, changing their mineralogy and chemical composition (Nicholson 1993; Verma et al. 2005; Pandarinath et al. 2008). Complex zoned alteration patterns have been well documented from a large number of important hydrothermal ore deposit types, including submarine-volcanogenic massive sulphide (Finlow-Bates and Stumpfl 1981; MacLean and Kranidiotis 1987), mesothermal Au (Kerrich and Fyfe 1981; Neall and Phillips 1987; Böhlke 1989; Piantone et al. 1994), porphyry copper (Lowell and Guilbert 1970; Hedenquist and Richards 1998), and epithermal $\mathrm{Au}-(\mathrm{Ag})$ deposits (Arribas 1995; Hedenquist and Arribas 1999). The geochemical expressions of mineral deposits and mine wastes in the environment ultimately derive from the interaction of rock (mineral), water, and biota. During rock-water interactions, concentrations of dissolved constituents typically increase, and minerals undergo transformations that affect the subsequent mobility and bioavailability of various elements. The geochemistry of rock-water interaction is 
also dependent on geologic setting. For example, massive sulfide deposits and resultant mine wastes can affect the environment through several pathways. Oxidative weathering of pyrite can generate highly acidic conditions, which in turn enhance the solubility of metals from other sulfide minerals and from gangue silicate and carbonate minerals. The acid and metals collectively affect surface- and ground-water quality and associated aquatic ecosystems and drinking-water supplies (Gunduz et al. 2007; Gunduz and Baba 2008; Seal et al. 2008). Similarly, weathering of volcanic rocks has also been addressed in some studies of volcanic islands (Louvat et al. 2008). According to Dessert et al. (2009), the chemical weathering rate of volcanic rocks is $5-10$ times greater than the chemical weathering of granite and gneiss.

Silicified, propylitic, and argillic are three common alteration types of rock observed in many parts of the world. Propylitic alteration transforms partial or total phenocryst of maphic minerals, such as pyroxenes and hornblendes, and replaces them with neominerals, such as chlorite \pm epidot \pm carbonate. The zones of advanced argillic alteration are major exploration targets for shallow high-sulphidation $\mathrm{Cu}-\mathrm{Au}$ epithermal and deeper porphyrytype deposits (Lerouge et al. 2004). The formation of alunite results from the alteration of host volcanic and volcano-sedimentary rocks by acidic, sulphate-bearing hydrothermal fluids (Hemley et al. 1969). Argilic alteration is associated with the process of forming of vuggy silica, which is composed of quartz, pyrite, and minor rutile. Altered rocks have a reddish-yellow-white color. The process of argillisation represents hydrolytic base leaching form all aluminous phases and under acid sulfate water. Many springs have been detected in the vicinity of the alteration zones. In general, $\mathrm{Al}+\mathrm{K}$ and $\mathrm{Mg}+\mathrm{Ca}+\mathrm{Fe}$ have been enriched in the argillic and propylitic alteration types, respectively. $\mathrm{Ca}, \mathrm{Mg}$, and $\mathrm{Fe}$ were leached during argillic alteration, whereas strong $\mathrm{Na}$ leaching is evident in all alteration types. The leaching or enrichment of elements depends on various environmental conditions (Karakaya et al. 2007). Bau et al. (1998) determined the following order of mobility in spring waters: $\mathrm{Na}>\mathrm{Ca} \approx \mathrm{Mn}>$ $\mathrm{Sr} \approx \mathrm{Mg}>\mathrm{Fe}>\mathrm{Al}$. Gislason et al. (1996), in a study of rivers in Iceland, observed a trend of $\mathrm{Na}>\mathrm{K}>\mathrm{Ca} \approx$ $\mathrm{Mg}>\mathrm{Sr}>\mathrm{Al}>\mathrm{Mn}>\mathrm{Fe}$ in an area with prevalent young $(0.2 \mathrm{Ma})$ basalts and a trend of $\mathrm{Na}>\mathrm{Ca} \approx \mathrm{Mg} \approx$ $\mathrm{K}>\mathrm{Sr}>\mathrm{Mn}>\mathrm{Fe}>1$ in an area with widespread, relatively old (7.7 Ma) basalts (Karakaya et al. 2007).

Widespread and intense zones of silicified, propylitic, and argillic alteration are present in the Çan volcanics of Biga Peninsula, northwest Turkey. Many springs have developed in the vicinity of these alteration zones, and they demonstrate different physicochemical and isotopic characteristics. This study focuses on two such springs in
Kirazl1 area (Kirazlı and Balaban springs) with distinct quality patterns. The rock-water interactions in these two springs were assessed from a geochemical point of view, and a general explanation for different quality patterns was developed based on water quality coupled with rock geochemistry from the outcropping alteration zones. Temporal variations in water quality were also observed by four distinct samples collected in different seasons. Isotopic compositions of the two springs were also used to determine the circulation patterns of groundwater through these alternation zones.

\section{General Characteristics of the Study Area}

The study area is located within the administrative boundaries of Çanakkale province on Biga Peninsula of northwestern Turkey (Fig. 1). Çanakkale is a world renowned settlement for the Dardanelle strait, the ancient Trojan city (Troy), the famous sea war and Gallipoli landing in World War I. The Village of Kirazlı is approximately $40 \mathrm{~km}$ southeast of Çanakkale and is a small mountain settlement with a total population of 191 people. The village is situated on Çanakkale-Çan state highway, and local economy is mostly dependent on forestry and animal husbandry. A limited amount of agriculture is performed in the village due to lack of agricultural land.

The morphology of the project area represents general characteristics of mountainous topography. The most prominent hill in the area is Kirazlı Mountain, which is $811 \mathrm{~m}$ above mean sea level (Fig. 1). The village takes its name from the mountain and is situated to the northern slopes of the mountain at an average elevation of approximately $400 \mathrm{~m}$. Small creeks, including but not limited to Kargacık, Hacıkarı, and Gökbüyet, drain the mountain and discharge into Atikhisar Reservoir, which serves the water supply system of Çanakkale city. The two springs (Kirazl1 and Balaban) that were studied within the scope of this work originate from the northern slopes of the mountain and feed Gökbüyet Creek. Although these two water resources are only approximately $1 \mathrm{~km}$ apart, they demonstrate different quality characteristics, which are discussed in detail in this article.

The climatic conditions in the project area resemble a transition zone between Mediterranean and Black Sea climate zones. Based on the data set collected during 1972 to 2005 (Fig. 2), the annual mean temperature at Çanakkale meteorological station was recorded to be $14.9^{\circ} \mathrm{C}$, with a mean monthly minimum of $2.2^{\circ} \mathrm{C}$ in February and a mean monthly maximum of $27.4^{\circ} \mathrm{C}$ in July (Fig. 2). The mean annual precipitation totals at the same station during the period 1970 through 2007 was $585.5 \mathrm{~mm}$ and distributed 
Fig. 1 The study area

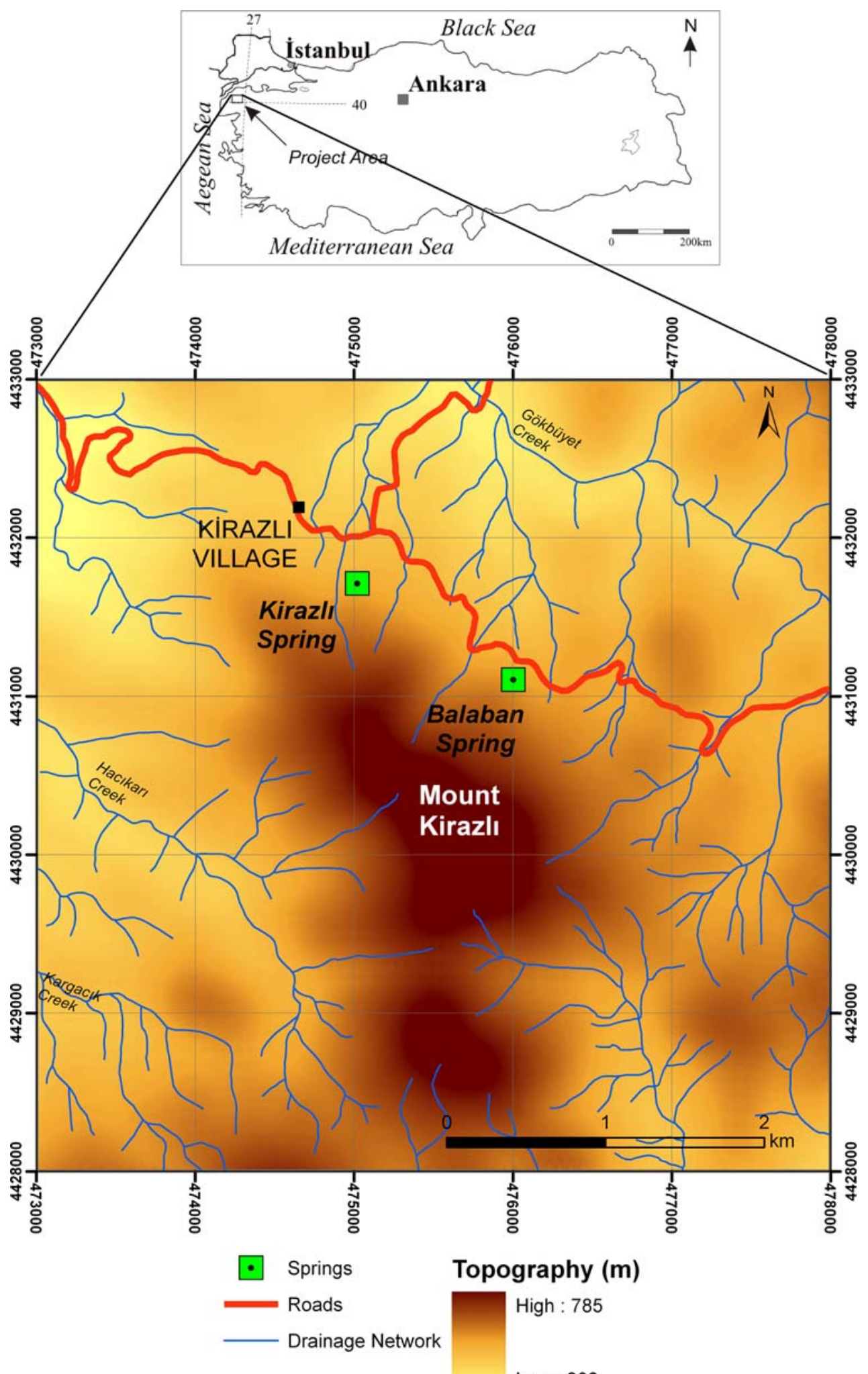

Low : 232

annually (Fig. 3). Of all monthly totals recorded in the station, the highest value was obtained in January 1995 (total mean $258 \mathrm{~mm}$ ), whereas the lowest values with no recordable precipitation totals were recorded in July and
August during a number of years. Thus, highest precipitation totals are observed in late fall and winter months, whereas lowest precipitation totals are observed during summer. 
The study area is generally covered with forest. The vegetation pattern consists mostly of scrub oak and various shrubs reaching to heights of approximately 3 to $4 \mathrm{~m}$. There are isolated zones of 20- to 30-year-old pines. Clear cutting and replantation of the forest have taken place in certain areas within the project area. Forestry and forest products are the primary source of income for the local people.

\section{Geologic and Hydrogeological Settings}

The study area is located in Biga Peninsula, which is an active tectonic region. Basement rocks of the peninsula are composed of Paleozoic aged metamorphic rocks, such as schist and marble, which are commonly known as the Kazdağ group. Rocks of the so-called Karakaya complex, such as sandstone, shale, ophiolite, and metavolcanics, were settled on this group with a tectonic boundary. Volcanic and sedimentary rock series cover these units in different parts of the peninsula. Volcanic rocks are dominant rock types in the region. Most of these rocks are altered and fractured due to the effects of active faults. Basement rocks are composed of Oligocene-age volcanic rocks, such as andesite, dacite, rhyodacite, basalt, tuff, and agglomerate. Several mineral deposits, including numerous industrial metals as well as some precious metals, have been found in the alteration zones or fractured parts of these volcanic rocks. Neogene-age sedimentary rocks overlie these rocks. These sediments consist mostly of fine grained components, such as sand, silt, and clay, and may include thick coal veins in different layers. All of the rocks are covered by Quaternary-age alluvium, which has a heterogeneous loose structure and is composed of gravel, sand, silt, and clay. The general geology of Biga Peninsula is given in Fig. 4.

Tertiary volcanism started to become active after lower Eocene and lasted until Upper Miocene. Outcrops of this volcanism can be observed at Biga Peninsula. In the first phase of this volcanism, andesitic and, partially, dacitic lava, tuff, and agglomerate formations were formed within the regional volcanic units. In the second phase, the volcanism, which was affected by tectonism, changed its form and dikes, and local lava flows (in the form of trachyandesite and black outcrops of basalt) were formed. Within the study area, these volcanic units are known as Kirazlı volcanites.

Kirazlı area was formed within calc-alkaline to alkaline Biga volcanic field on the eastern margin of an interpreted caldera. The property is underlayed by a sequence of andesitic to dacitic lithic (fragmental) and crystal-lithic tuffs whose primary textures are largely obscured by a blanket of intense silica and clay alteration. The volcanic units at Kirazlı consist of Miocene age of an undifferentiated, heterogeneous volcanic assemblage of dacitic to andesitic formation, which hosts alteration zones and precious metal mineralization. The volcanic units, which are situated along the eastern rim of a caldera, are made up of predominantly lithic tuffs with subordinate crystal-lithic tuff, ash-flow, and/or ash fall tuffs and epiclastic units. The lithic tuffs are generally massive and locally thin-bedded, ranging from fine to very coarse grained. The crystal-lithic tuffs resemble the lithic tuffs and contain feldspar, mafic minerals, and some quartz (Ciftehan 2006).

In the study area, these volcanic units are complex and contain three different types of alterations (i.e., silicification, argillization, and propylitization). Silicification has created three types of zones with similar characteristics. A strongly silicified zone can be observed locally in spots around the summit of Mount Kirazlı within a silicified and argillized zone. In the outer parts of these zones, a medium level of silicification can also be observed that forms a medium silicified region. Underneath these silicified zones, an argillic alteration can be seen (Fig. 5). In the lower elevations of silicified and argillized zones, propylitization
Fig. 2 Time series graph for annual total precipitation and mean annual temperature at Çanakkale meteorological station

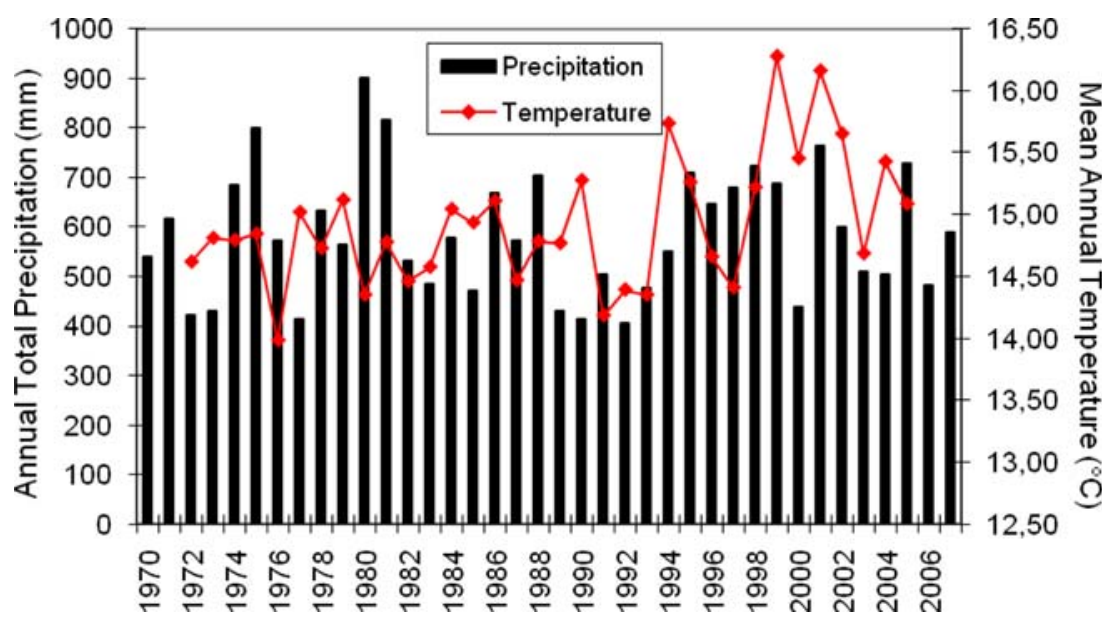


Fig. 3 Monthly precipitation and temperature averages at Çanakkale meteorological station

Fig. 4 Regional geology in Biga Peninsula (modified from General Directorate of Mineral Research, Exploration [2002])
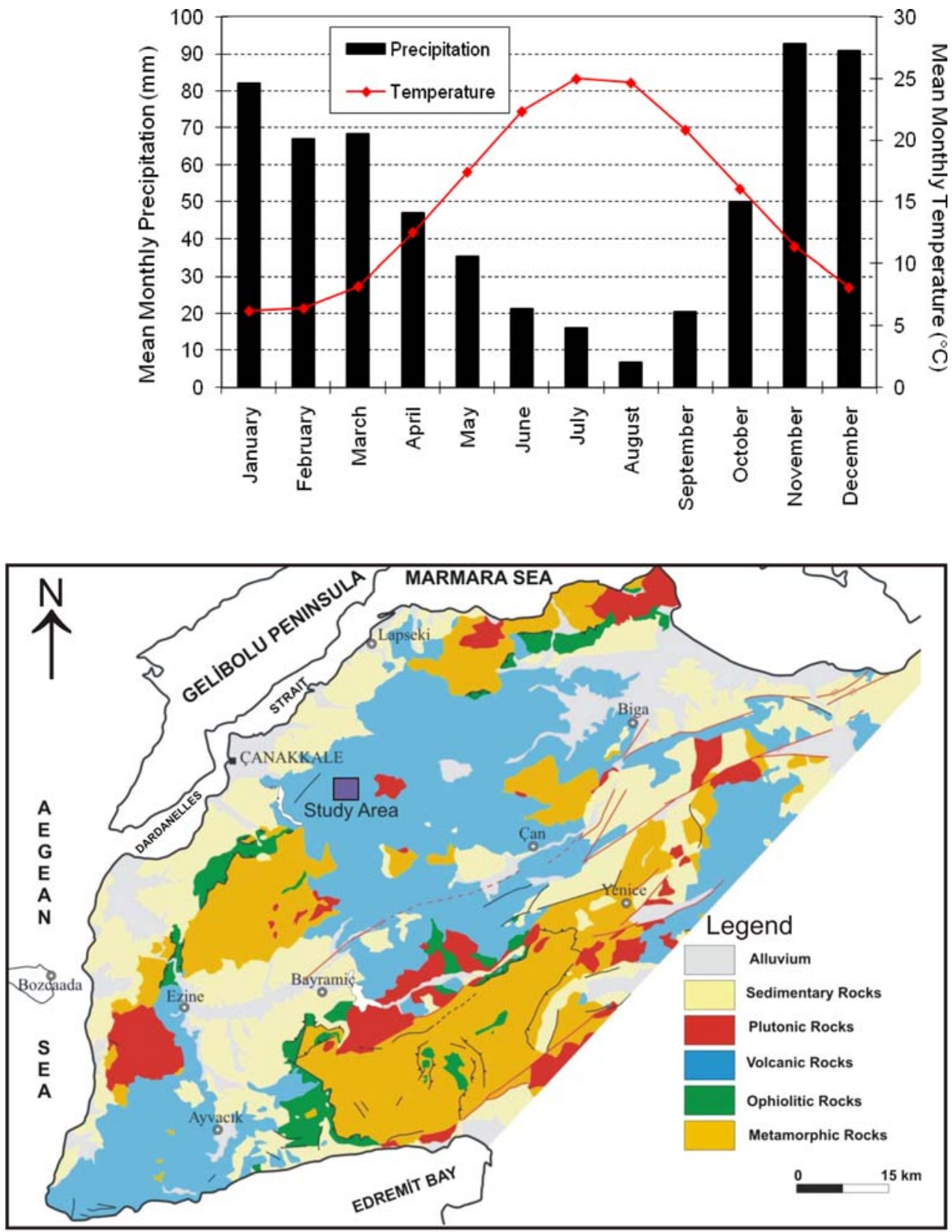

can be observed in the volcanic rocks of the study area. Propylitization is typically observed with andesite lava. Finally, conglomerate, sandstone, and mudstone units, which belong to Karakaya formation as previously discussed, are also observed in eastern and southern parts of the study area (Baba et al. 2009).

The hydrogeology of the Çanakkale-Çan region (where the project area is located) is primarily dominated by general hydrogeological features of volcanic units. These units cover a wide area by partially cutting and occasionally overlying the units of Karakaya Formation. Although the dike units of volcanism are mostly composed of andesite and rarely dacite, the surface units of volcanism generally consist of andesitic tuff, agglomerate, and basic lava flows. Grey-brown silicified volcanic rocks are observed in the upper sections of volcanites and along the slopes. Silicified zones of these volcanites are typically situated as a cap over the volcanic rocks. In addition, tuff and agglomerate are partially or completely silicified and are observed in harmony with locally altered Çan volcanites. The silicified volcanites in the study demonstrate fractured aquifer characteristics. The angles of fractures in this unit range between $70^{\circ}$ and $90^{\circ}$. Dense argillic alteration, demonstrating impervious properties due to its high clay content, can also be seen below the silicified alteration zone. These clayish zones act as a barrier beneath the fractured aquifer (Baba et al. 2009). 
Fig. 5 Local geology of Kirazlı area

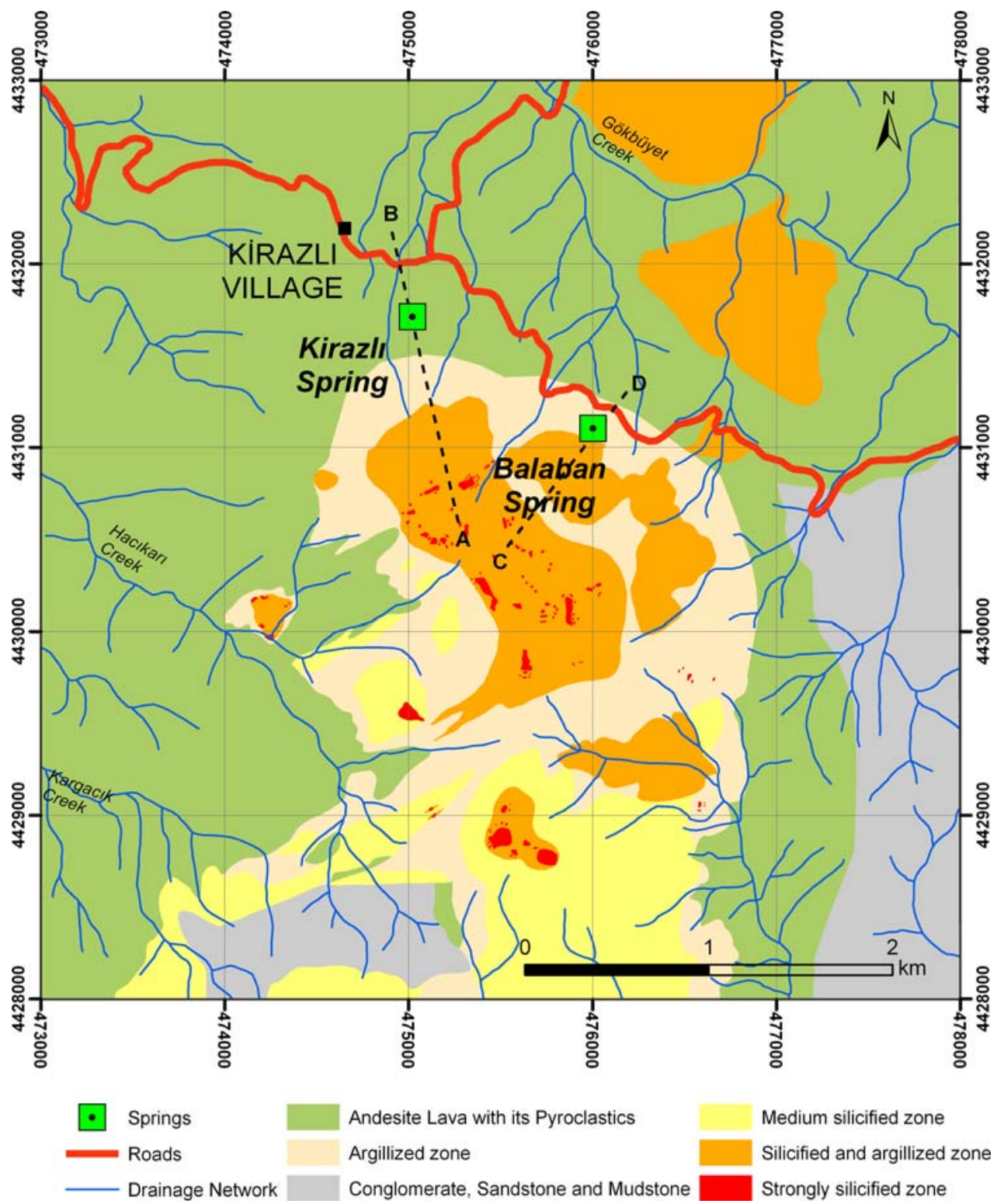

In general, most of the springs in the study area surface out from the boundary between fractured aquifer (silicified zone) and impervious boundary (argillic zone). The flow rates of these springs range between 0.01 and $3 \mathrm{~L} / \mathrm{s}$. However, other units in the volcanic rocks, such as tuff and agglomerate, do not provide good aquifer characteristics and do not supply significant quantities of water.

\section{Materials and Methods}

As a part of the field studies, a sampling campaign was conducted on water and soil media. The hydrogeochemical sampling program included a total of two waterquality sampling stations, representing the two springs in Kirazlı area, and six rock and soil samples from the immediate vicinity of these springs. Within the scope of the hydrogeochemical sampling program, water samples were obtained from Balaban and Kirazlı springs (Fig. 1) during three different time periods (2005, 2006, and 2007). These samples were analyzed for physicochemical constituents and isotopic characteristics. The physicochemical analysis for these spring waters included primary field parameters (i.e., temperature, $\mathrm{pH}$, and electrical conductivity), major anions and cations (i.e., sodium, potassium, calcium, magnesium, chloride, bicarbonate, and sulfate), and heavy metals and trace elements (including but not limited to aluminum, arsenic, barium, chromium, cobalt, cupper, iron, lithium, manganese, nickel, lead, and zinc). Furthermore, samples were also analyzed for their isotopic composition (i.e., oxygen-18 $\left[{ }^{18} \mathrm{O}\right]$, deuterium, and tritium). 
For water-quality monitoring, three sets of samples were taken from each spring: a 1000-mL sample for major anions and cations; a 1000-mL sample for isotopes; and a 100-mL sample for heavy metals and trace elements. Electrical conductivity (EC), temperature, and $\mathrm{pH}$ values were measured in situ with a multiparameter instrument. All water samples were filtered through $0.45-\mu \mathrm{m}$ filter article and stored in polyethylene bottles at $4^{\circ} \mathrm{C}$. Major anion and cation analysis were conducted in Çanakkale Onsekiz Mart University laboratories using standard chromotographic and titrimetric methods. The heavy metals and trace elements were acidified to $\mathrm{pH}<2$ conditions by adding $0.5 \mathrm{~N} \mathrm{HNO}_{3}$ to prevent complex formation of trace elements with oxygen and then analyzed by inductively coupled plasma-mass spectroscopy (ICP-MS) at Canadian ACME Laboratories. The concentrations of deuterium (D) and ${ }^{18} \mathrm{O}$ isotopes in water samples were determined in the isotope laboratories of State Hydraulic Works in Ankara, Turkey. The analysis was carried out in accordance with the standards defined by the International Atomic Energy Agency (Attendorn and Bowen 1997). In this regard, ${ }^{18} \mathrm{O}$ and $\mathrm{D}$ analyses were conducted using an MS technique that had an uncertainty of $\pm 0.05 \%$ and $\pm 1.0 \%$, respectively. These values are expressed conventionally in delta notation as per-mil deviation from the V-SMOW (Vienna Standard Mean Ocean Water) (Verhagen et al. 1991). Tritium analysis was conducted in the laboratories of Karst Research and Application Centre of Hacettepe University, Turkey, with a liquid scintillation counter after electrolytic enrichment of the water samples with an error of \pm 0.8 tritium units (TU) (Attendorn and Bowen 1997).

Within the scope of the rock and soil sampling program, rock samples were obtained from six different locations near Balaban and Kirazlı springs (Fig. 1). A total of $2 \mathrm{~kg}$ rock and soil samples were collected from a depth of 0 to $20 \mathrm{~cm}$. Major and minor element contents of these samples were then analyzed. A microwave digestion technique was used for total dissolution of the samples. Approximately $0.1 \mathrm{~g}$ soil sample was digested using a combination of concentrated $\mathrm{HF}-\mathrm{HNO}_{3}-\mathrm{HCl}$ (Heinrichs and Herrmann 1990). The solution was transferred into acid-cleaned Teflon beakers and dried on a heating plate. To completely remove fluoride ions, a $5-\mathrm{ml}$ volume of $\mathrm{HCl}$ was added twice to the dried residue and then evaporated to near dryness. The sequential extraction technique has recently been widely used to gain a better understanding of geochemical processes by which heavy metals are fixed and remobilized (Hall et al. 1996). Considering this fact, $2 \mathrm{~g}$ of soil samples were sequentially fractionated using the procedure given by Zeien and Brümmer (1989) to determine metal concentrations in different soil samples (Thuy et al. 2000). Samples were then analyzed for the measured elements using ICP-MS at Canadian ALS Chemex Laboratories.

\section{Results and Discussion}

The results of the study are presented in three subsections. First, the rock geochemistry is discussed based on the results of the rock and soil sampling program in parallel to local geology. Second, the hydrogeochemistry of the two springs is presented with close reference to their isotopic composition where water chemistry is linked to water age and circulation patterns within the local geologic formations. Third, the isotopic composition is discussed.

\section{Rock Geochemistry}

Based on detailed field surveys and analysis of available borehole data of mining companies that conduct exploration activities in the region, three types of alteration were found within the study area: (1) silicification (Fig. 6), (2) argillization (Fig. 7), and (3) propylitization (Fig. 8). In essence, these alterations make this area a rich mineral deposition area where extensive mining exploration is

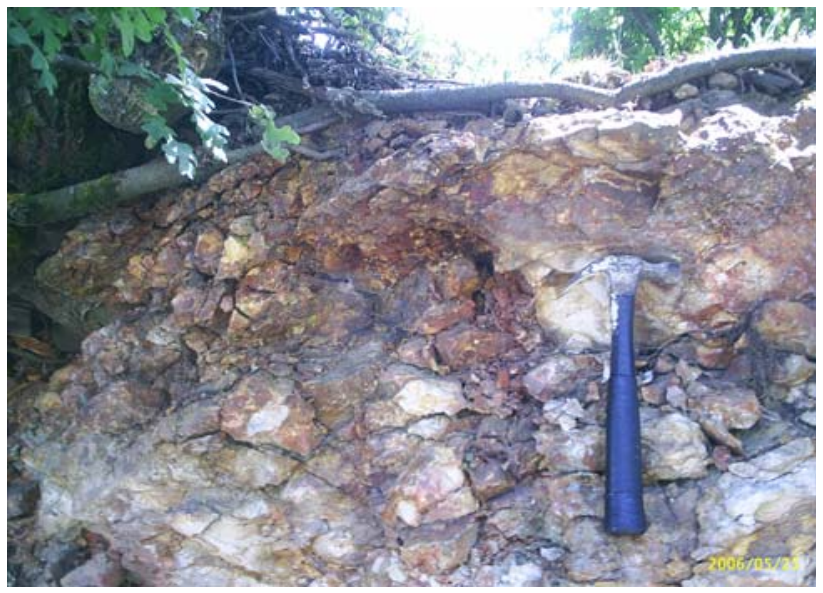

Fig. 6 Silicification in Kirazlı area

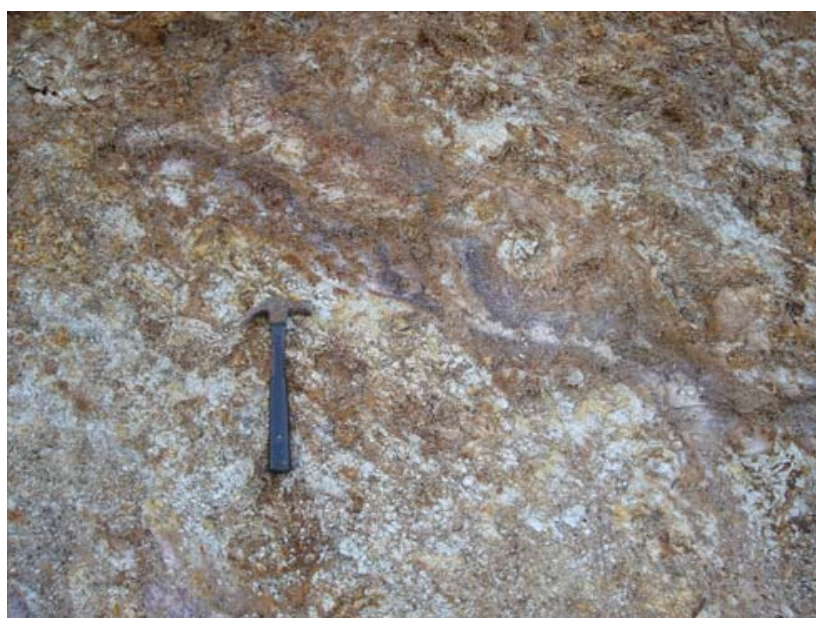

Fig. 7 Argillization in Kirazlı area 


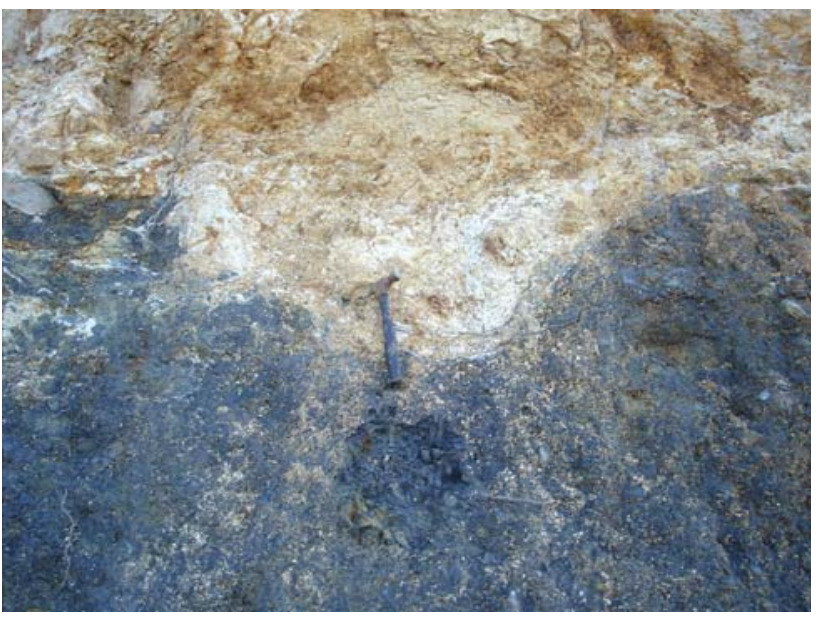

Fig. 8 Argillization (upper light-colored section) and propylitization (lower dark-colored section) in Kirazlı area

currently underway. Assessment of the field surveys showed that Mount Kirazlı is capped by a massive-sized, pervasively silicified volcanic unit that was effective in shaping the local morphology. The silicification is monophase and is believed to be formed as a result of two possible processes. The first possible explanation is a regional sulphidic silicification of the Neogene volcanics, which in part coincided with some stage of caldera formation. The depth of formation might be shallow near the water table in permeable fragmental and tuff units. The second possible explanation is the formation through silicified volcanics by way of the remobilization of silica by acidic fluids percolating downward from an overlying acid-leached zone. At the level of the paleo-water table, the fluids were neutralized, thus inducing silica precipitation (Ciftehan 2006). The formation mechanism of this silicification has not yet been clarified and would possibly require detailed assessment of borehole data from mining companies that conduct exploration activities for some precious metals including but not limited to gold. These massive and densely silicified units contain relict fragmental texture of the volcanics. Furthermore, the silicified units are strongly pyritic, contain local healed hydrothermal breccias, and locally retain the bedding planes of the original flows. The color of these early-phase silicified volcanics is tan, brown, or light gray (Ciftehan 2006).

The second alteration type, argillization, is related to faulting and areas of hydrothermal alteration and hypogene mineralization. An advanced argillic alteration assemblage is present at Kirazlı beneath the main silica cap. The assemblage ranges from clay-rich ( $>60 \%$ clay) to quartz (silica)-rich ( $>60 \%$ quartz) members. Finally, the third alteration, propylitization, is a fairly recent event, which is most readily evidenced by pyrophyllite clots, masses, and veinlets. Pyrophyllite is associated with late-stage, variable mineral assemblage veins. Some kaolinite may be after this pyrophyllite. Alunite occurs as small disseminations or as larger masses with a distinctive light pink color and may be allied with the pyrophyllite previously noted (Ciftehan 2006).

Considering these three alterations developed in the area, six soil samples were collected from the immediate vicinity of the springs with particular reference to the outcropping units. The results of rock and soil sampling,

Table 1 Major element distribution in soil/rock samples

\begin{tabular}{|c|c|c|c|c|c|c|c|c|c|c|c|}
\hline & Unit & S1 & S2 & S3 & S4 & S5 & S6 & Min & Max & Mean & SD \\
\hline$X(m)$ & $\mathrm{m}$ & 476130 & 476175 & 476150 & 476050 & 475950 & 475500 & - & - & - & - \\
\hline $\mathrm{Y}(\mathrm{m})$ & $\mathrm{m}$ & 4431240 & 4431187 & 4431185 & 4431180 & 4431200 & 4431320 & - & - & - & - \\
\hline $\mathrm{SiO}_{2}$ & $\%$ & 62.36 & 66.99 & 71.09 & 58.70 & 63.71 & 58.27 & 58.27 & 71.09 & 63.52 & 4.93 \\
\hline $\mathrm{Al}_{2} \mathrm{O}_{3}$ & $\%$ & 16.52 & 14.79 & 14.53 & 18.28 & 22.01 & 15.70 & 14.53 & 22.01 & 16.97 & 2.82 \\
\hline $\mathrm{Fe}_{2} \mathrm{O}_{3}$ & $\%$ & 4.85 & 5.68 & 2.40 & 3.33 & 1.33 & 7.01 & 1.33 & 7.01 & 4.10 & 2.13 \\
\hline $\mathrm{CaO}$ & $\%$ & 0.06 & 0.20 & 0.04 & 0.10 & 0.10 & 1.54 & 0.04 & 1.54 & 0.34 & 0.59 \\
\hline $\mathrm{MgO}$ & $\%$ & 0.88 & 0.88 & 0.72 & 0.94 & 0.58 & 1.31 & 0.58 & 1.31 & 0.89 & 0.25 \\
\hline $\mathrm{Na}_{2} \mathrm{O}$ & $\%$ & 0.18 & 0.15 & 0.18 & 0.28 & 0.89 & 1.50 & 0.15 & 1.50 & 0.53 & 0.55 \\
\hline $\mathrm{K}_{2} \mathrm{O}$ & $\%$ & 6.75 & 3.40 & 3.76 & 3.65 & 3.71 & 2.14 & 2.14 & 6.75 & 3.90 & 1.52 \\
\hline $\mathrm{Cr}_{2} \mathrm{O}_{3}$ & $\%$ & 0.01 & 0.02 & 0.04 & $<0.01$ & $<0.01$ & $<0.01$ & 0.01 & 0.04 & 0.02 & 0.02 \\
\hline $\mathrm{TiO}_{2}$ & $\%$ & 0.52 & 1.06 & 0.99 & 0.70 & 0.84 & 0.58 & 0.52 & 1.06 & 0.78 & 0.22 \\
\hline $\mathrm{MnO}$ & $\%$ & 0.05 & 0.22 & 0.01 & 0.02 & $<0.01$ & 0.01 & 0.01 & 0.22 & 0.06 & 0.09 \\
\hline $\mathrm{P}_{2} \mathrm{O}_{5}$ & $\%$ & 0.16 & 0.14 & 0.08 & 0.10 & 0.04 & 0.08 & 0.04 & 0.16 & 0.10 & 0.04 \\
\hline $\mathrm{SrO}$ & $\%$ & 0.02 & 0.01 & 0.01 & $<0.01$ & 0.01 & 0.03 & 0.01 & 0.03 & 0.02 & 0.01 \\
\hline $\mathrm{BaO}$ & $\%$ & 0.35 & 0.07 & 0.09 & 0.06 & 0.05 & 0.07 & 0.05 & 0.35 & 0.12 & 0.12 \\
\hline LOI & $\%$ & 6.11 & 4.57 & 4.67 & 12.35 & 6.75 & 10.30 & 4.57 & 12.35 & 7.46 & 3.18 \\
\hline Total & $\%$ & 98.81 & 98.18 & 98.61 & 98.51 & 99.97 & 98.54 & 98.18 & 99.97 & 98.77 & 0.62 \\
\hline
\end{tabular}


Table 2 Minor element distribution in soil and rock samples

\begin{tabular}{|c|c|c|c|c|c|c|c|c|c|c|c|}
\hline & Unit & $\mathrm{S} 1$ & $\mathrm{~S} 2$ & $\mathrm{~S} 3$ & $\mathrm{~S} 4$ & S5 & S6 & Min & Max & Mean & $\mathrm{SD}$ \\
\hline $\mathrm{Al}$ & $\%$ & 0.41 & 0.52 & 0.32 & 1.31 & 1.39 & 0.97 & 0.32 & 1.39 & 0.82 & 0.47 \\
\hline As & ppm & 52.10 & 67.10 & 42.60 & 14.60 & 6.80 & 9.80 & 6.80 & 67.10 & 32.17 & 25.21 \\
\hline $\mathrm{Ba}$ & ppm & 340.00 & 160.00 & 270.00 & 140.00 & 50.00 & 160.00 & 50.00 & 340.00 & 186.67 & 102.70 \\
\hline $\mathrm{Ca}$ & $\%$ & 0.05 & 0.13 & 0.03 & 0.06 & 0.04 & 0.37 & 0.03 & 0.37 & 0.11 & 0.13 \\
\hline $\mathrm{Cd}$ & ppm & 0.01 & 5.71 & 0.05 & 0.83 & 0.02 & 0.06 & 0.01 & 5.71 & 1.11 & 2.27 \\
\hline $\mathrm{Ce}$ & ppm & 40.90 & 45.60 & 60.40 & 57.60 & 31.00 & 16.70 & 16.70 & 60.40 & 42.03 & 16.48 \\
\hline $\mathrm{Cr}$ & ppm & 103.00 & 97.00 & 184.00 & 48.00 & 25.00 & 12.00 & 12.00 & 184.00 & 78.17 & 63.70 \\
\hline $\mathrm{Cu}$ & ppm & 46.10 & 46.60 & 6.70 & 15.00 & 4.80 & 68.00 & 4.80 & 68.00 & 31.20 & 25.97 \\
\hline $\mathrm{Fe}$ & $\%$ & 3.31 & 3.57 & 1.33 & 2.07 & 0.42 & 3.65 & 0.42 & 3.65 & 2.39 & 1.34 \\
\hline In & ppm & 0.02 & 0.02 & 0.01 & 0.01 & 0.02 & 0.02 & 0.01 & 0.02 & 0.02 & 0.00 \\
\hline $\mathrm{K}$ & $\%$ & 0.51 & 0.14 & 0.22 & 0.27 & 0.15 & 0.15 & 0.14 & 0.51 & 0.24 & 0.14 \\
\hline $\mathrm{La}$ & ppm & 20.50 & 20.60 & 28.10 & 25.50 & 15.90 & 8.60 & 8.60 & 28.10 & 19.87 & 6.97 \\
\hline $\mathrm{Li}$ & ppm & 0.50 & 6.30 & 1.10 & 4.40 & 1.20 & 2.00 & 0.50 & 6.30 & 2.58 & 2.28 \\
\hline $\mathrm{Mg}$ & $\%$ & 0.04 & 0.11 & 0.02 & 0.11 & 0.03 & 0.25 & 0.02 & 0.25 & 0.09 & 0.09 \\
\hline $\mathrm{Mn}$ & ppm & 95.00 & 1690.00 & 62.00 & 169.00 & 24.00 & 62.00 & 24.00 & 1690.00 & 350.33 & 658.11 \\
\hline Mo & ppm & 1.00 & 1.13 & 0.66 & 1.09 & 0.43 & 0.55 & 0.43 & 1.13 & 0.81 & 0.30 \\
\hline $\mathrm{Na}$ & $\%$ & 0.04 & $<0.01$ & 0.03 & 0.01 & 0.01 & 0.02 & 0.01 & 0.04 & 0.02 & 0.01 \\
\hline $\mathrm{Ni}$ & ppm & 1.70 & 66.10 & 3.10 & 3.90 & 1.50 & 2.30 & 1.50 & 66.10 & 13.10 & 25.98 \\
\hline $\mathrm{P}$ & ppm & 680.00 & 550.00 & 270.00 & 410.00 & 130.00 & 260.00 & 130.00 & 680.00 & 383.33 & 204.32 \\
\hline $\mathrm{Pb}$ & ppm & 107.00 & 114.00 & 16.50 & 17.60 & 5.10 & 7.70 & 5.10 & 114.00 & 44.65 & 51.28 \\
\hline $\mathrm{Rb}$ & ppm & 15.20 & 8.90 & 11.30 & 13.30 & 7.60 & 7.40 & 7.40 & 15.20 & 10.62 & 3.20 \\
\hline S & $\%$ & 0.82 & 0.04 & 0.30 & 1.67 & 0.04 & 0.15 & 0.04 & 1.67 & 0.50 & 0.64 \\
\hline $\mathrm{Sb}$ & ppm & 1.98 & 1.28 & 0.76 & 0.18 & 0.13 & 0.24 & 0.13 & 1.98 & 0.76 & 0.74 \\
\hline $\mathrm{Sc}$ & ppm & 1.80 & 2.40 & 1.10 & 2.70 & 2.70 & 4.00 & 1.10 & 4.00 & 2.45 & 0.98 \\
\hline $\mathrm{Sr}$ & ppm & 59.80 & 12.70 & 14.60 & 4.40 & 4.90 & 63.90 & 4.40 & 63.90 & 26.72 & 27.55 \\
\hline $\mathrm{Th}$ & ppm & 5.10 & 8.50 & 7.20 & 1.20 & 1.10 & 12.70 & 1.10 & 12.70 & 5.97 & 4.48 \\
\hline $\mathrm{Tl}$ & ppm & 0.49 & 0.15 & 0.33 & 0.49 & 0.27 & 0.14 & 0.14 & 0.49 & 0.31 & 0.16 \\
\hline $\mathrm{U}$ & ppm & 0.38 & 0.66 & 0.17 & 0.18 & 0.14 & 1.03 & 0.14 & 1.03 & 0.43 & 0.35 \\
\hline V & ppm & 9.00 & 15.00 & 6.00 & 15.00 & 17.00 & 22.00 & 6.00 & 22.00 & 14.00 & 5.73 \\
\hline W & ppm & 0.34 & 0.17 & 0.13 & 0.11 & 0.06 & 0.09 & 0.06 & 0.34 & 0.15 & 0.10 \\
\hline $\mathrm{Y}$ & ppm & 2.27 & 7.05 & 2.14 & 30.20 & 2.76 & 20.10 & 2.14 & 30.20 & 10.75 & 11.74 \\
\hline $\mathrm{Zn}$ & ppm & 20.00 & 493.00 & 6.00 & 48.00 & 13.00 & 27.00 & 6.00 & 493.00 & 101.17 & 192.50 \\
\hline
\end{tabular}

and some basic statistics are given in Tables 1 and 2 for major constituents and minor elements, respectively. Generally, results show that all rock samples consist of $>80 \% \mathrm{SiO}_{2}, \mathrm{Al}_{2} \mathrm{O}_{3}$, and $\mathrm{Fe}_{2} \mathrm{O}_{3}$ (Table 1). Particularly, $\mathrm{SiO}_{2}$ contents reached to levels $\leq 71 \%$ (at S3), which is a clear indication of the silicified zone. When minor elements are considered, aluminum is the most significant minor element (mean value $0.82 \%$ ). Highest levels, $>1.0 \%$, were observed at sampling locations S4, S5, and S6. These high levels are also consistent with high dissolved aluminum levels in Kirazlı spring water as discussed later in the text. The sulfur levels were also found to be high, representing the presence of alteration in the area. Finally, arsenic, antimony, and copper levels were also high and showed a parallel trend to each other in the study area.

\section{Hydrogeochemistry}

Mount Kirazlı has a significant potential for water resources and serves the water supply systems of four villages. Of the five major springs that originate from the mountain, the Kirazlı and Balaban springs are particularly important for the local inhabitants of Kirazlı village because they feed the domestic water supply system. Furthermore, the waters of these two springs are believed to have healing potential for various gastrointestinal illnesses and thus attract tourists to the area. Both springs originate from the outcropping volcanic rocks and demonstrate typical characteristics of water resources that originate from volcanic formations. The outcropping volcanic rocks in the study area are extremely fractured, and water that seeps through these 
Fig. 9 Cross-sectional view of Balaban and Kirazlı springs

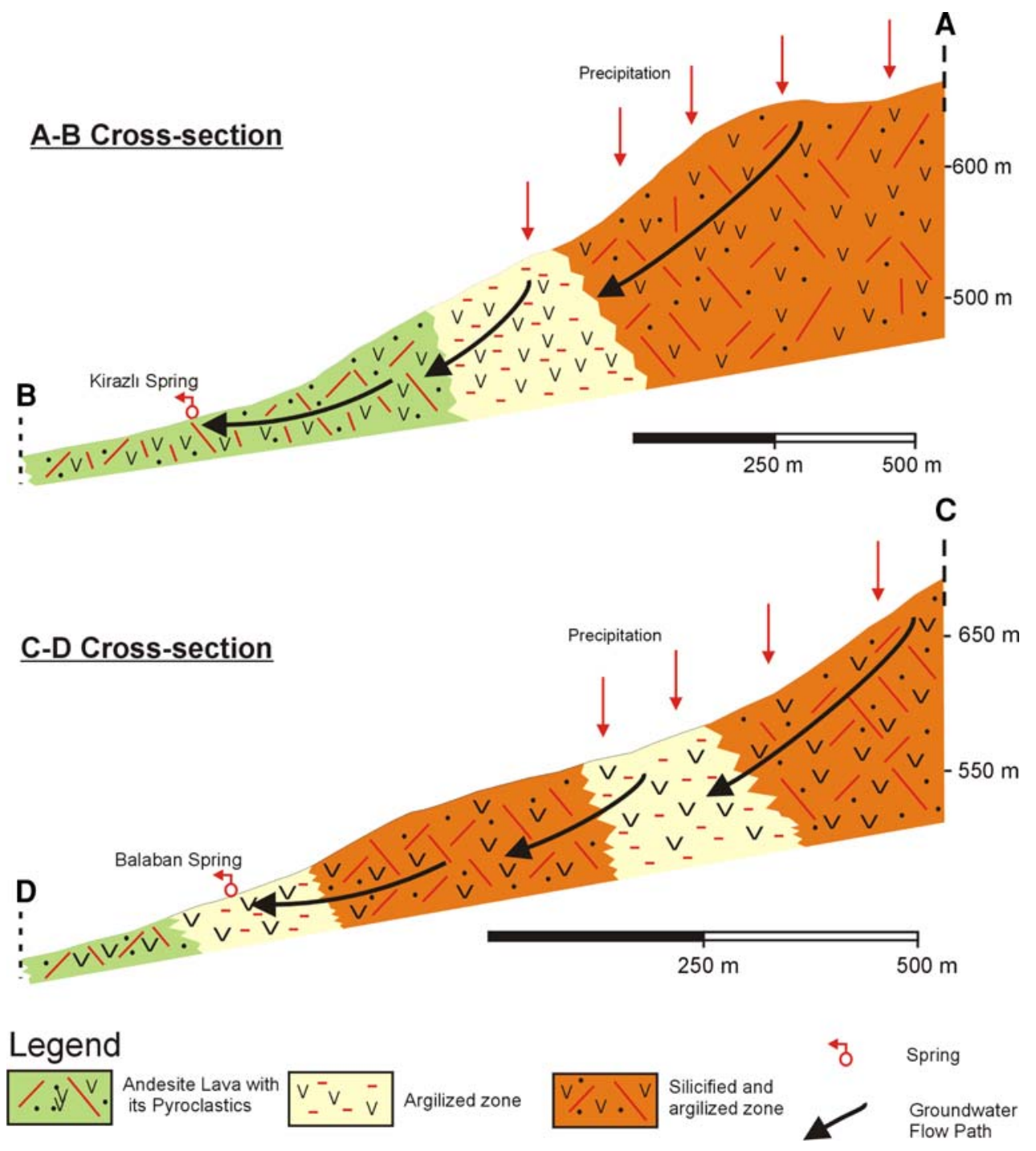

cracks surface out from altered rocks found at lower elevations (Fig. 9). Both the Kirazl1 and Balaban springs are representative samples for this morphology and are believed to have formed in connection with the fractured aquifer.

Based on these fundamentals, the hydrogeochemical properties of the two springs are analyzed according to four different sets of water samples collected at different time periods spanning the period September 2005 to April 2007. The results are given in Table 3 , and major statistics and corresponding national and international standards are given in Table 4. According to the results, the waters of the Balaban and Kirazlı springs are acidic in nature (mean $\mathrm{pH}$ values of 5.66 and 3.74, respectively). These values are of the range (i.e., 6.5 to 9.5) stated in national and international quality standards (ITASHY 2005; EPA 2003) for drinking water. These low $\mathrm{pH}$ values are also responsible for the increased solubility of numerous trace elements as discussed later in the text. When the electrical conductivity values of the samples were analyzed, it was seen that Kirazl1 spring has higher values compared with Balaban spring (mean values 388.75 and $98.25 \mu \mathrm{S} / \mathrm{cm}$, respectively). Although both springs demonstrate high-quality spring water with low conductivity values, Kirazlı spring clearly contains higher levels of dissolved constituents, which are primarily associated with its long retention time in the altered formation and comparably low $\mathrm{pH}$ values. Furthermore, both $\mathrm{pH}$ and electrical conductivity showed a rather constant trend with limited amount of seasonal variation as shown in Fig. 10. The decreased conductivity and increased pH in samples collected on January 19, 2006 and March 28, 2007, are related to seasonal precipitation, which is predominant from January through March in the region.

With regard to major ions, Kirazlı spring demonstrates a pattern of relatively higher ion concentrations than Balaban spring (Table 3). Sodium, potassium, calcium, and magnesium concentrations were found to be higher in Kirazli waters (mean values 17.96, 2.77, 12.47, and $3.82 \mathrm{mg} / \mathrm{L}$, 
Table 3 Physicochemical characteristics of Balaban and Kirazlı springs

\begin{tabular}{|c|c|c|c|c|c|c|c|c|c|}
\hline & & \multicolumn{8}{|c|}{ Location/date } \\
\hline & & \multicolumn{4}{|c|}{ Balaban spring } & \multicolumn{4}{|c|}{ Kirazlı spring } \\
\hline & & $\begin{array}{l}\text { B1 } \\
22 / 10 / 2005\end{array}$ & $\begin{array}{l}\text { B2 } \\
19 / 01 / 2006\end{array}$ & $\begin{array}{l}\text { B3 } \\
01 / 08 / 2006\end{array}$ & $\begin{array}{l}\text { B4 } \\
28 / 03 / 2007\end{array}$ & $\begin{array}{l}\text { K1 } \\
22 / 10 / 2005\end{array}$ & $\begin{array}{l}\text { K2 } \\
19 / 01 / 2006\end{array}$ & $\begin{array}{l}\text { K3 } \\
01 / 08 / 2006\end{array}$ & $\begin{array}{l}\text { K4 } \\
28 / 03 / 2007\end{array}$ \\
\hline $\mathrm{T}$ & $\mathrm{C}$ & 13.2 & 10 & 10 & 9.9 & 13.8 & 6.7 & 7 & 8.7 \\
\hline EC & $\mu \mathrm{S} / \mathrm{cm}$ & 88 & 100 & 114 & 91 & 374 & 390 & 381 & 410 \\
\hline $\mathrm{pH}$ & - & 6.5 & 5.1 & 5.3 & 5.7 & 3.8 & 4 & 3.5 & 3.6 \\
\hline $\mathrm{Na}$ & ppm & 9.97 & 9.44 & 9.93 & 10.96 & 16.87 & 17.87 & 17.27 & 19.84 \\
\hline $\mathrm{K}$ & ppm & 1.11 & 1.24 & 0.94 & 1.17 & 2.73 & 3.07 & 2.44 & 2.84 \\
\hline $\mathrm{Ca}$ & ppm & 4.4 & 3.78 & 3.55 & 3.59 & 13.28 & 12.94 & 11.82 & 11.85 \\
\hline $\mathrm{Mg}$ & ppm & 1.36 & 1.55 & 1.39 & 1.23 & 3.84 & 3.96 & 3.79 & 3.67 \\
\hline $\mathrm{Cl}$ & ppm & 18 & 13 & 13 & 15 & 27 & 28 & 25 & 32 \\
\hline $\mathrm{HCO}_{3}$ & ppm & 10 & 15 & 12 & 17 & 4 & 5 & 5 & 7 \\
\hline $\mathrm{SO}_{4}$ & ppm & 8 & 7 & 4.7 & 10 & 56 & 54 & 55 & 60 \\
\hline $\mathrm{Al}$ & $\mathrm{ppb}$ & 278 & 118 & 109 & 106 & 13206 & 15698 & 13183 & 13166 \\
\hline $\mathrm{Ba}$ & $\mathrm{ppb}$ & 95.77 & 88.6 & 81.03 & 91.52 & 22 & 17.83 & 16.28 & 18.71 \\
\hline Co & $\mathrm{ppb}$ & 0.82 & 0.84 & 0.66 & 0.81 & 20.36 & 21.62 & 16.62 & 19.29 \\
\hline $\mathrm{Cu}$ & $\mathrm{ppb}$ & 0.9 & 0.9 & 1.1 & 1.3 & 6.9 & 22.7 & 3.7 & 2.2 \\
\hline $\mathrm{Fe}$ & $\mathrm{ppb}$ & 21 & 14 & 22 & 18 & 551 & 1123 & 561 & 1174 \\
\hline $\mathrm{Li}$ & $\mathrm{ppb}$ & 0.9 & 0.6 & 0.7 & 0.8 & 10.6 & 11 & 9.4 & 9.2 \\
\hline $\mathrm{Mn}$ & $\mathrm{ppb}$ & 8 & 13.65 & 6.79 & 8.45 & 409.22 & 407.41 & 364.53 & 424.73 \\
\hline $\mathrm{Ni}$ & $\mathrm{ppb}$ & 0.6 & 0.5 & 0.8 & 0.7 & 7.2 & 7.9 & 7.2 & 7.6 \\
\hline $\mathrm{Pb}$ & $\mathrm{ppb}$ & 1 & 0.8 & 0.9 & 1.2 & 28.8 & 51.2 & 22.6 & 19.2 \\
\hline S & ppm & 6 & 6 & 2 & 4 & 50 & 62 & 42 & 47 \\
\hline $\mathrm{Si}$ & $\mathrm{ppb}$ & 5257 & 4637 & 3646 & 4366 & 15518 & 15516 & 11774 & 14064 \\
\hline $\mathrm{Zn}$ & $\mathrm{ppb}$ & 5.2 & 7.1 & 5.2 & 6.1 & 77.5 & 82 & 85.1 & 85.1 \\
\hline
\end{tabular}

respectively). The corresponding values in Balaban waters were $10.08,1.12,3.83$, and $1.38 \mathrm{mg} / \mathrm{L}$, respectively. Thus, the cation species in Kirazlı spring are approximately twice their corresponding levels in Balaban spring. A similar pattern was also observed in major anion concentrations. Chloride, bicarbonate, and sulfate levels were 28, 5.25, and $56.25 \mathrm{mg} / \mathrm{L}$ in Kirazl1 and 14.75, 13.50, and $7.43 \mathrm{mg} / \mathrm{L}$ in Balaban springs, respectively. The concentrations in Kirazlı waters were twice their corresponding levels in Balaban waters, with the exception of bicarbonate levels. There was an inverse relation in bicarbonate levels, which is attributed to the relatively lower $\mathrm{pH}$ levels in Kirazlı because bicarbonate alkalinity decreases as $\mathrm{pH}$ becomes acidic. Thus, the major anion and cation data further support the extended duration of contact of Kirazlı waters with the altered formation. Similarly, major ion results show that Balaban water seeps out from a shallow jointed aquifer.

On the basis of major ion concentrations, the Piper and Schoeller diagrams of Kirazlı and Balaban springs are drawn and shown in Figs. 11 and 12. When the Piper diagram is analyzed, it can be seen that Balaban spring is relatively rich in $\mathrm{Na}-\mathrm{Ca}-\mathrm{Cl}-\mathrm{HCO}_{3}$ (sodium-calcium-chloride and bicarbonate type), whereas Kirazlı spring is relatively rich in $\mathrm{Na}-\mathrm{Ca}-\mathrm{SO}_{4}-\mathrm{Cl}$ (sodium-calcium-sulfate and chloride type). When major ion levels in both springs are compared with national and international drinking water standards, all parameters are within the allowable ranges.

The influence of alteration and the duration of contact in Kirazlı and Balaban springs are clearly observed when the heavy metal and trace element results are assessed. At least one order of magnitude difference between concentration values are listed in Table 3 in most of the elements (Fig. 13). In particular, aluminum concentrations were found to be two orders of magnitude larger in Kirazli waters (mean value $13813.25 \mu \mathrm{g} / \mathrm{L}$ ). The corresponding mean in Balaban waters was calculated to be $152.75 \mu \mathrm{g} / \mathrm{L}$. This result is extremely important in understanding the distinct water-quality pattern in two springs that are $<1 \mathrm{~km}$ apart. Furthermore, the levels measured in Kirazlı spring are two orders of magnitude greater than the standard value of $200 \mu \mathrm{g} / \mathrm{L}$. Although oral consumption of high aluminum content waters have been reported to cause Alzheimer's disease (Nieboer et al. 1995; Nordberg 1998; Polizzi et al. 2002), detailed medical studies are to be conducted on the 
Table 4 Statistical summary of water quality in Balaban and Kirazlı springs and comparison with water-quality standards

\begin{tabular}{|c|c|c|c|c|c|c|c|c|c|c|}
\hline & \multicolumn{2}{|c|}{ Minimum } & \multicolumn{2}{|c|}{ Maximum } & \multicolumn{2}{|l|}{ Mean } & \multicolumn{2}{|l|}{ SD } & \multirow[t]{2}{*}{ ITASHY } & \multirow[t]{2}{*}{ EPA } \\
\hline & Balaban & Kirazlı & Balaban & Kirazlı & Balaban & Kirazlı & Balaban & Kirazlı & & \\
\hline $\mathrm{T}$ & 9.90 & 6.70 & 13.20 & 13.80 & 10.78 & 9.05 & 1.62 & 3.29 & 25 & - \\
\hline $\mathrm{EC}$ & 88.00 & 374.00 & 114.00 & 410.00 & 98.25 & 388.75 & 11.67 & 15.61 & 2500 & - \\
\hline $\mathrm{pH}$ & 5.10 & 3.50 & 6.53 & 4.00 & 5.66 & 3.74 & 0.63 & 0.22 & $6.5-9.5$ & $6.5-8.5$ \\
\hline $\mathrm{Na}$ & 9.44 & 16.87 & 10.96 & 19.84 & 10.08 & 17.96 & 0.64 & 1.32 & 200 & - \\
\hline K & 0.94 & 2.44 & 1.24 & 3.07 & 1.12 & 2.77 & 0.13 & 0.26 & - & - \\
\hline $\mathrm{Ca}$ & 3.55 & 11.82 & 4.40 & 13.28 & 3.83 & 12.47 & 0.39 & 0.75 & 200 & - \\
\hline $\mathrm{Mg}$ & 1.23 & 3.67 & 1.55 & 3.96 & 1.38 & 3.82 & 0.13 & 0.12 & 50 & - \\
\hline $\mathrm{Cl}$ & 13.00 & 25.00 & 18.00 & 32.00 & 14.75 & 28.00 & 2.36 & 2.94 & 250 & 250 \\
\hline $\mathrm{HCO}_{3}$ & 10.00 & 4.00 & 17.00 & 7.00 & 13.50 & 5.25 & 3.11 & 1.26 & - & - \\
\hline $\mathrm{SO}_{4}$ & 4.70 & 54.00 & 10.00 & 60.00 & 7.43 & 56.25 & 2.20 & 2.63 & 250 & 250 \\
\hline $\mathrm{Al}$ & 106.00 & 13166.00 & 278.00 & 15698.00 & 152.75 & 13813.25 & 83.66 & 1256.61 & 200 & 200 \\
\hline $\mathrm{Ba}$ & 81.03 & 16.28 & 95.77 & 22.00 & 89.23 & 18.71 & 6.21 & 2.42 & & \\
\hline Co & 0.66 & 16.62 & 0.84 & 21.62 & 0.78 & 19.47 & 0.08 & 2.13 & - & - \\
\hline $\mathrm{Cu}$ & 0.90 & 2.20 & 1.30 & 22.70 & 1.05 & 8.88 & 0.19 & 9.42 & 2000 & 1000 \\
\hline $\mathrm{Fe}$ & 14.00 & 551.00 & 22.00 & 1174.00 & 18.75 & 852.25 & 3.59 & 342.74 & 200 & 300 \\
\hline $\mathrm{Li}$ & 0.60 & 9.20 & 0.90 & 11.00 & 0.75 & 10.05 & 0.13 & 0.89 & - & - \\
\hline $\mathrm{Mn}$ & 6.79 & 364.53 & 13.65 & 424.73 & 9.22 & 401.47 & 3.03 & 25.83 & 50 & 50 \\
\hline $\mathrm{Ni}$ & 0.50 & 7.20 & 0.80 & 7.90 & 0.65 & 7.48 & 0.13 & 0.34 & 20 & - \\
\hline $\mathrm{Pb}$ & 0.80 & 19.20 & 1.20 & 51.20 & 0.98 & 30.45 & 0.17 & 14.39 & 10 & 15 \\
\hline S & 2.00 & 42.00 & 6.00 & 62.00 & 4.50 & 50.25 & 1.92 & 8.50 & & \\
\hline $\mathrm{Si}$ & 3646.00 & 11774.00 & 5257.00 & 15518.00 & 4476.50 & 14218.00 & 667.55 & 1767.45 & & \\
\hline $\mathrm{Zn}$ & 5.20 & 77.50 & 7.10 & 85.10 & 5.90 & 82.43 & 0.91 & 3.59 & 5000 & 5000 \\
\hline
\end{tabular}

local inhabitants of Kirazlı before conclusive remarks are made regarding the health impacts of water quality in the Kirazlı area.

In addition to aluminum, iron, lead, manganese, nickel, and zinc concentrations are much higher in Kirazlı waters (mean values $852.25,30.45$, 401.47, 7.48, and $82.43 \mu \mathrm{g} / \mathrm{L}$, respectively) than their corresponding levels in Balaban waters (mean values 18.75, 0.98, 9.22, 0.65, and $5.90 \mu \mathrm{g} / \mathrm{L}$, respectively; Fig. 13) Of these elements, iron, lead, and manganese levels $(200,10$, and $50 \mu \mathrm{g} / \mathrm{L}$, respectively) were found to exceed the standard values depicted in ITASHY (2005), which would mean that Kirazlı waters are essentially not suitable for human consumption.

The main reason for obtaining high element concentrations in Kirazlı spring is related to longer retention times of Kirazlı waters in altered geologic formations compared with Balaban waters (Fig. 9). Despite the fact that these two springs are close to each other, Balaban waters are fed by rain water that seeped into the volcanic cracks and that surfaced out from the altered zone located directly below the silicified zone. Thus, rock-water interactions are of short duration in this spring. This is clearly observed from silicium levels in spring waters. Although both springs are essentially recharged from the same silicified unit, mean silicium levels are much higher in Kirazlı waters $(14218 \mu \mathrm{g} / \mathrm{L})$ compared with Balaban waters $(4476.5 \mu \mathrm{g} / \mathrm{L})$, emphasizing the relatively longer contact times of Kirazlı waters with the silicified zone. In addition, there is not sufficient amount of time for extensive mineral enrichment in Balaban waters, and $\mathrm{pH}$ levels did not fall $<4$, at which point significant element dissolution could start to occur. In particular, duration of contact and $\mathrm{pH}$ levels act in a parallel fashion and increase element levels in Kirazlı spring.

\section{Isotopic Composition}

The isotopic composition of water samples collected from both springs are listed in Table 5. The corresponding $\delta^{18} \mathrm{O}-$ $\delta^{2} \mathrm{H}$ diagram is shown in Fig. 14. As seen from Fig. 14, the samples from 2005 were taken from along the Mediterranean meteoric water line, whereas the samples from 2006 were taken from along the Marmara meteoric water line. This difference is attributed to the seasonal precipitation pattern because year 2006 was recorded to be a relatively wet year compared with year 2005 .

Based on these results, Balaban and Kirazlı springs have been aged at $>55$ years old according to their tritium 

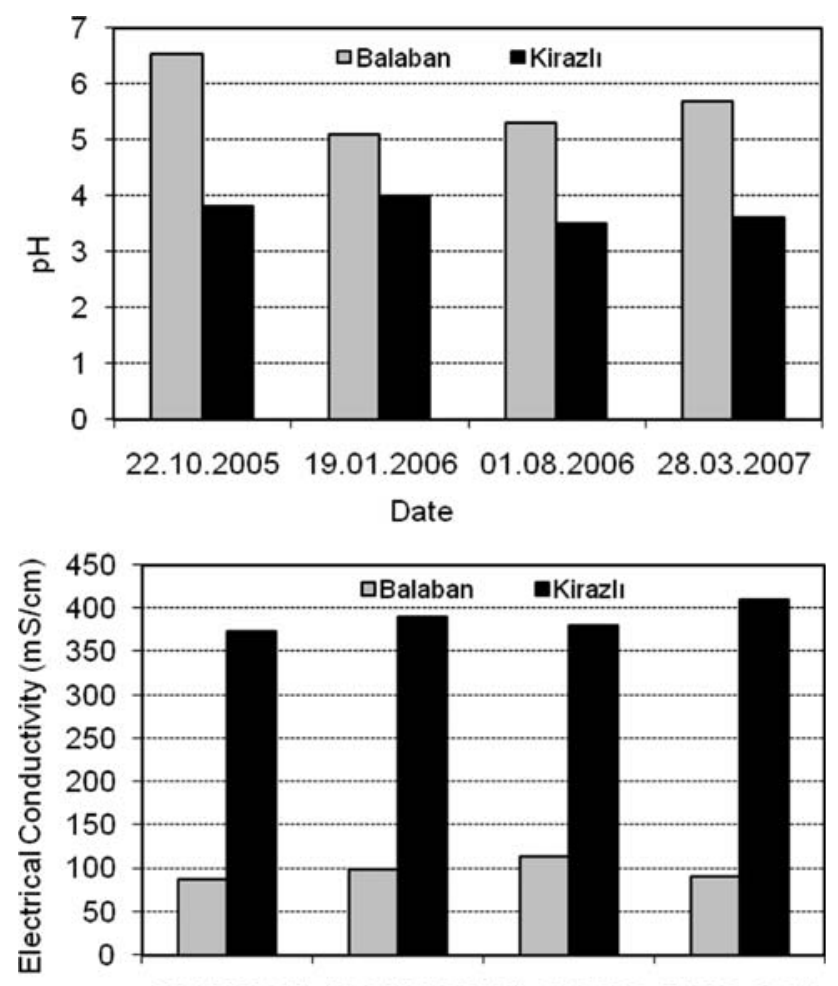

22.10.2005 19.01.2006 01.08.2006 28.03.2007

Date

Fig. 10 Time variations of $\mathrm{pH}$ and electrical conductivity in Balaban and Kirazlı springs

levels. Kirazlı spring is more enriched than Balaban spring based on the ${ }^{18} \mathrm{O}$ and $\mathrm{D}$ values. Moreover, the tritium values show that Kirazlı spring water is older than Balaban

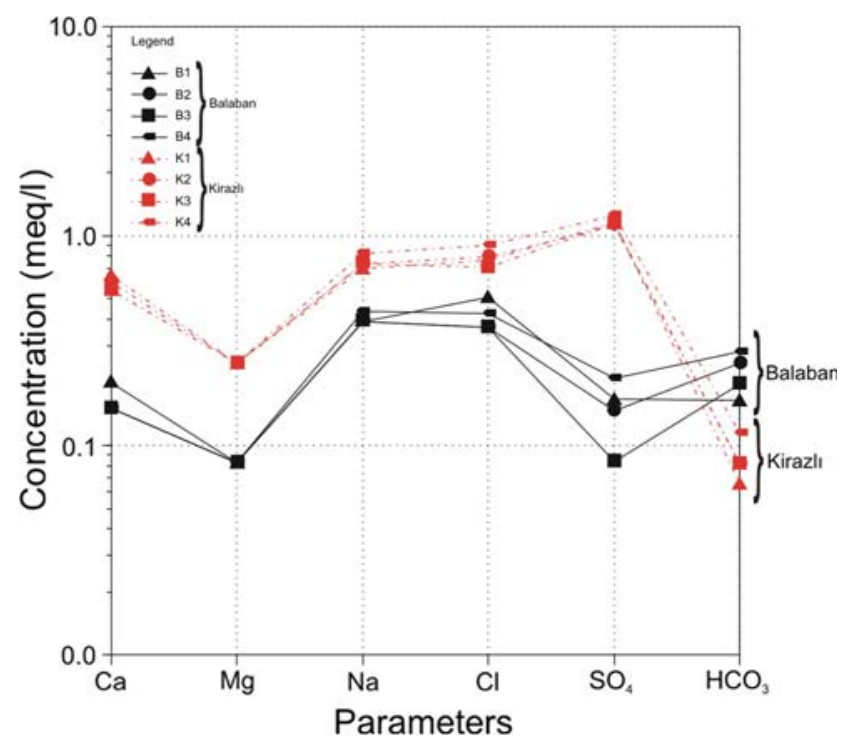

Fig. 12 Schoeller diagram of water samples

spring water. Furthermore, Kirazlı spring water has also been shown to be in contact with altered rocks longer than Balaban spring water according to the relatively high chloride and EC values.

\section{Conclusion}

Rock-water interaction is an important mechanism in determining the overall quality pattern of groundwater resources. Particularly with the increased influence of
Fig. 11 Piper diagram of water samples

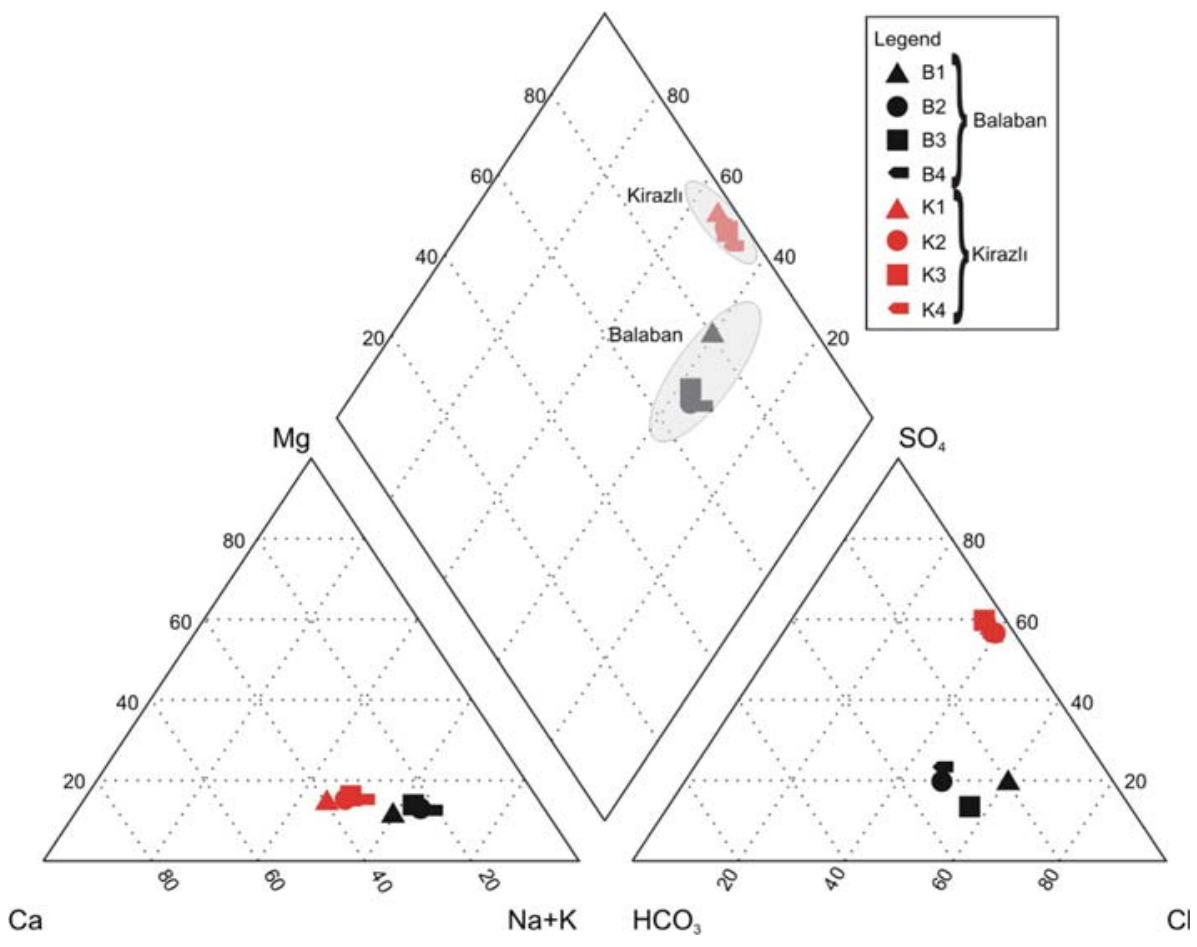




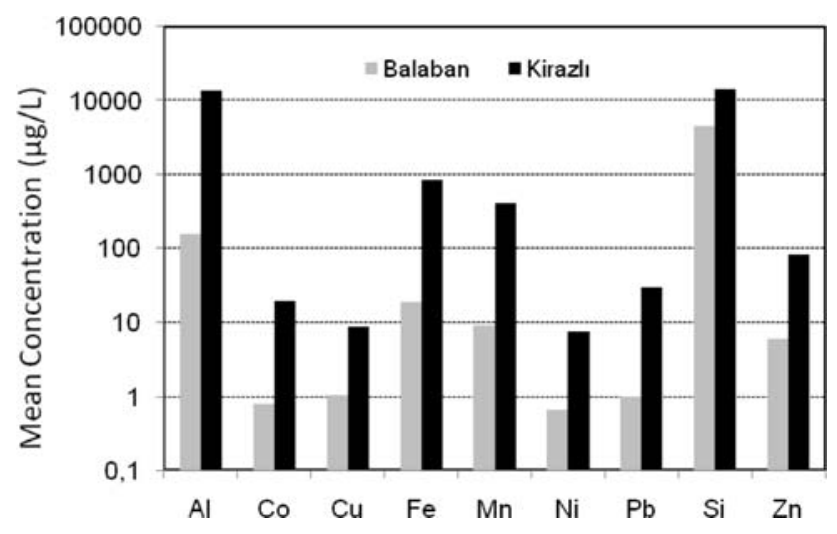

Fig. 13 Mean values of heavy-metal and trace elements in Balaban and Kirazlı springs

Table 5 Isotopic composition of Kirazlı and Balaban springs

\begin{tabular}{lllllll}
\hline $\begin{array}{l}\text { Sample } \\
\text { location }\end{array}$ & Date & $\delta \mathrm{D}$ & $\begin{array}{l}\mathrm{T} \\
(\mathrm{TU})\end{array}$ & $\delta^{18} \mathrm{O}$ & $\begin{array}{l}\mathrm{EC}(\mu \mathrm{S} / \\
\mathrm{cm})\end{array}$ & $\begin{array}{l}\mathrm{Cl} \\
(\mathrm{ppm})\end{array}$ \\
\hline Balaban & 22.10 .2005 & -45.22 & 2.84 & -8.3 & 88 & 18 \\
Kirazlı & 22.10 .2005 & -43.63 & 0.95 & -8.19 & 374 & 27 \\
Balaban & 14.03 .2006 & -52.11 & 2.96 & -8.22 & 100 & 13 \\
Kirazli & 14.03 .2006 & -51.26 & 1.13 & -8.15 & 390 & 28 \\
\hline
\end{tabular}

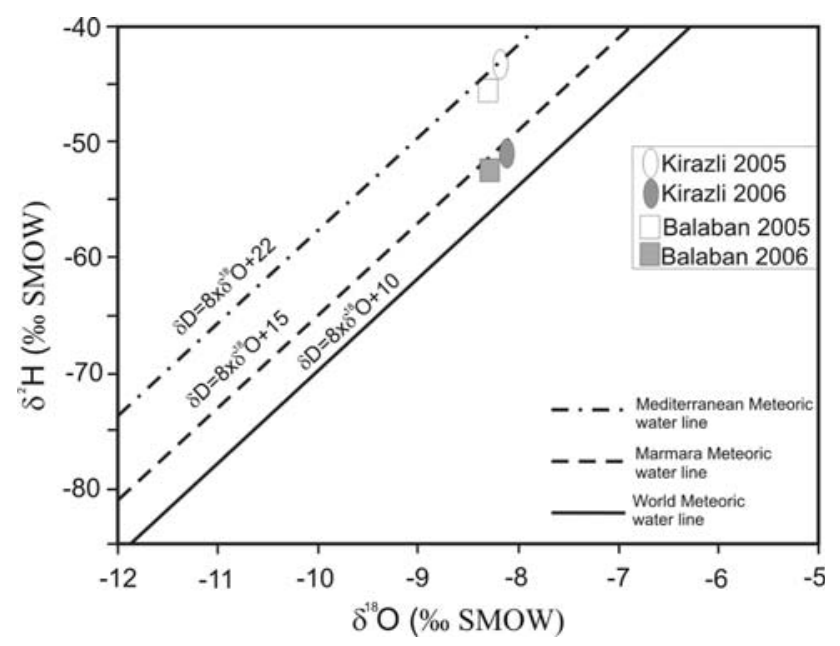

Fig. 14 Isotopic composition of Balaban and Kirazlı springs in 2005 and 2006

climate change (i.e., increased temperature and decreased precipitation amounts), this mechanism is believed to become more important in the future. Changes in recharge amounts and patterns would clearly have negative impacts on groundwater quality. In essence, decreases in groundwater recharge would necessitate the use of deeper and older groundwater that has had longer contact with associated rock. Increased ion concentrations-with particular reference to trace elements, such as arsenic and aluminum-would thus cause increased risks for human and environmental health.

Characteristic water quality of Balaban and Kirazl springs in Biga Peninsula, Turkey, provides a good example for rock-water interaction in general and for the influence of alteration zones in particular. Despite their close proximity $(<1 \mathrm{~km})$, these springs demonstrate very different water-quality patterns. Kirazlı spring has higher electrical conductivity, lower $\mathrm{pH}$, and elevated ionic composition than Balaban spring. Because both springs are essentially fed from the same recharge zone, the extent and the duration of contact of infiltrating rain waters determine the final quality pattern of each spring. Both geochemical data and isotopic composition show the fact that Kirazlı waters are more exposed to rock-water interactions in alteration zones of volcanic formations. Higher acidity and trace element concentrations further support this interaction pattern with very high aluminum, iron, and lead values in this spring compared with its counterpart. The levels of these elements were found to exceed the maximum allowable limits stated in national and international standards for drinking-water quality. This finding demonstrates the necessity for conducting detailed research on human health effects of consuming these waters.

Acknowledgements The authors thank the Turkish Academy of Sciences and the Scientific and Technological Research Council of Turkey for their support.

\section{References}

Arribas A Jr (1995) Characteristics of high-sulfidation epithermal deposits, and their relation to magmatic fluid. In: Thompson JFH (ed) Magmas, fluids and ore deposits [Shortcourse series 23]. Mineralogical Association of Canada, Canada, pp 419-454

Attendorn HG, Bowen R (1997) Radioactive and stable isotope geology. Chapman and Hall, London, $519 \mathrm{p}$

Baba A, Save D, Gunduz O, Gurdal G, Bozcu M, Sulun S et al (2009) The assessment of the mining activities in Çan Coal Basin from a medical geology perspective. Final report [in Turkish]. The Scientific and Technological Research Council of Turkey Project No. ÇAYDAG-106Y041, Ankara, Turkey

Bau M, Usui A, Pracejus B, Mita N, Kanai Y, Irber W et al (1998) Geochemistry of low-temperature water-rock interaction: evidence from natural waters, andesite, and iron-oxyhydroxide precipitates at Nishiki-Numa iron-spring, Hokkaido, Japan. Chem Geol 151:293-307

Böhlke JK (1989) Comparison of metasomatic reactions between a common $\mathrm{CO}_{2}$-rich vein fluid and diverse wall rocks: intensive variables, mass transfers, and Au mineralization at Alleghany, California. Econ Geol 84:291-327

Ciftehan H (2006) Kirazlı property exploration 2004-2005 year end report [unpublished report]. Teckcominco Exploration and Mining Inc, Ankara, Turkey

Dessert C, Gaillardet J, Dupre B, Schott J, Pokrovsky O (2009) Fluxes of high- versus low-temperature water-rock interactions in aerial volcanic areas: example from the Kamchatka Peninsula, Russia. Geochim Cosmochim Acta 73:148-169 
Environmental Protection Agency (2003) National primary drinking water standards. Office of Water, United States Environmental Protection Agency, EPA 816-F-03-016

Finlow-Bates T, Stumpfl EF (1981) The behavior of so-called immobile elements in hydrothermally altered rocks associated with volcanogenic submarine-exhalative deposits. Min Deposit 16:319-328

General Directorate of Mineral Research, Exploration (2002) Geological map of Turkey, scale 1:500.000. MTA, Ankara, Turkey

Gislason SR, Arnorsson S, Armannsson H (1996) Chemical weathering of basalt in southwest Iceland: effects of runoff, age of rocks and vegetative/glacial cover. Am J Sci 296:837-907

Gunduz O, Baba A (2008) Fate of acidic mining lakes in Can Lignite District, Turkey. In Proceedings of the XXXVI IAH congress integrating groundwater science and human well-being, Proceedings CD-ROM, 26 October-1 November 2009, Toyoma, Japan

Gunduz O, Okumusoglu D, Baba A (2007) Acidic mining lakes and their influence on water quality: a case study from Can (Canakkale)-Turkey. In: Trefry MG (ed) Proceedings of the 6th groundwater quality conference (GW07: securing groundwater quality in urban and industrial environments), Fremantle, Western Australia

Hall G, Vaive JE, Beer R, Hoashi M (1996) Selective leaches revisited, with emphasis on the amorphous $\mathrm{Fe}$ oxyhydroxide phase extraction. J Geochem Explor 56:59-78

Hedenquist JW, Arribas A Jr (1999) Epithermal gold deposits: I. Hydrothermal processes in intrusion-related systems, and II. Characteristics, examples and origin of epithermal gold deposits. In: Molnar F, Lexa J, Hedenquist JW (eds) Epithermal mineralization of the Western Carpathians. Society of Economic Geologists, Guidebook Series Vol. 31, pp 13-63

Hedenquist JW, Richards JP (1998) The influence of geochemical techniques on the development of genetic models for porphyry copper deposits. In: Richards JP, Larsen PB (eds) Techniques in hydrothermal ore deposits geology. Reviews in economic geology, vol 10, pp 235-256

Heinrichs H, Herrmann AG (1990) Praktikum der Analytischen Geochemie. Springer-Verlag, Berlin, Germany, pp 352-355

Hemley JJ, Hostetler PB, Gude AJ, Mountjoy WT (1969) Some stability relations of alunite. Econ Geol 64:599-612

Henley RW, Truesdell AH, Barton PB Jr (1984) Fluid-mineral equilibria in hydrothermal systems: society of economic geologists reviews in economic geology, Robertson JM (series ed), vol 1. The Economic Geology Publishing Company, El Paso, TX, $267 \mathrm{p}$

Insani Tüketim Amaçlı Sular Hakkındaki Yönetmelik (ITASHY) (2005) Regulation on waters for human consumption [in Turkish]. Official Gazette dated 17/02/2005, No.25730, Ankara, Turkey

Karakaya N, Karakaya MÇ, Nalbantçılar MT, Yavuz F (2007) Relation between spring-water chemistry and hydrothermal alteration in the Şaplıca volcanic rocks, Şebinkarahisar (Giresun, Turkey). J Geochem Explor 93:35-46

Kerrich R, Fyfe WS (1981) The gold-carbonate association: source of $\mathrm{CO}_{2}$ and $\mathrm{CO}_{2}$-fixation reactions in Archean lode gold deposits. Chem Geol 33:265-294
Lerouge C, Flehos C, Kunov A, Hikov A, Georgieva S, Lescuyer JL et al (2004) Stable isotope study and origin of alunite from advanced argillic alteration systems in Bulgaria. In: Proceedings of Annual Scientific Conference of Bulgarian Geological Society, pp 16-17

Louvat P, Gislason SR, Allegre CJ (2008) Chemical and mechanical erosion rates in Iceland as deduced from river dissolved and solid material. Am J Sci 308:679-726

Lowell JD, Guilbert JM (1970) Lateral and vertical alterationMineralization zoning in porphyry copper deposits. Econ Geol 65:373-408

MacLean WH, Kranidiotis P (1987) Immobile elements as monitors of mass transfers in hydrothermal alteration: Phelps Dodge massive sulfide deposit, Matagami, Quebec. Econ Geol 82:951962

Neall FB, Phillips GN (1987) Fluid-wall rock interaction in an Archean hydrothermal gold deposit: a thermodynamic model for the Hunt mine, Kambalda. Econ Geol 82:1679-1694

Nicholson K (1993) Geothermal fluids-Chemistry and exploration techniques. Springer-Verlag, Berlin, Germany

Nieboer E, Gibson BL, Oxman AD, Kramer JR (1995) Health effects of aluminum: a critical review with emphasis on aluminum in drinking water. Environ Rev 3:29-81

Nordberg G (1998) Metals: chemical properties and toxicity, aluminum. In: Stellman JM (ed) Encyclopedia of occupational health and safety, vol III, 4th edn. International Labour Office, Geneva, pp 63.2-63.3

Pandarinath K, Dulski P, Torres-Alvarado IS, Verma SP (2008) Element mobility during the hydrothermal alteration of rhyolitic rocks of the Los Azufres geothermal field, Mexico. Geothermics 37:53-72

Piantone P, Wu X, Touray JC (1994) Zoned hydrothermal alteration and genesis of the gold deposit at Le Chatelet (French Massif Central). Econ Geol 89:757-777

Polizzi S, Pira E, Ferrara M, Bugiani M, Papaleo A, Albera R et al (2002) Neurotoxic effects of aluminum among foundry workers and Alzheimer's disease. Neurotoxicology 23:761-774

Seal RR II, Hammarstrom JM, Johnson AN, Piatak NM, Wandless GA (2008) Environmental geochemistry of a Kuroko-type massive sulfide deposit at the abandoned Valzinco mine, Virginia, USA. Appl Geochem 23:320-342

Thuy HT, Tobschall HJ, An PV (2000) Distribution of heavy metals in urban soils-A case study of Danang-Hoian area (Vietnam). Environ Geol 39:603-610

Verhagen BT, Geyh MA, Fröhlich K, With K (1991) Isotope hydrological methods for the quantitative evaluation of groundwater resources in arid and semi-arid areas. Research Reports of the Federal Ministry for Economic Cooperation of the Federal Republic of Germany, Bonn, Germany, pp 7-122

Verma SP, Torres-Alvarado IS, Satir M, Dobson PF (2005) Hydrothermal alteration effects in geochemistry and $\mathrm{Sr}, \mathrm{Nd}, \mathrm{Pb}$, and $\mathrm{O}$ isotopes of magmas from the Los Azufres geothermal field (Mexico): a statistical approach. Geochem J 39:141-163

Zeien H, Brümmer GW (1989) Chemische Extraktion zur Bestimmung von Schwermetallbindungsformen in Böden. Mitteilgn Dtsch Bodenkundl Gesellsch 59:505-510 